\title{
The future of Old Age Psychiatry in Africa
}

It is a popular belief that mental disorders in the elderly in Africa are less prevalent, less expensive to treat and not an important health care issue. Health problems facing African authorities are diverse. In South Africa where 32\% of the population is in the 0-14 year age group, a high percentage of health resources have been shifted to maternal and child care. ${ }^{1}$ Primary health care priorities address needs such as human immunodeficiency virus (HIV), tuberculosis and other infectious diseases. Thus, resources for mental health care are limited. Human resources for mental health care in Nigeria are dismal, with virtually all mental health personnel concentrated in urban areas where far less Nigerians reside. There are no specially separated mental health services for older adults in rural or urban Nigerian communities. ${ }^{2}$

Epidemiological studies are complex and costly and there are few representative estimates of dementia and other disorders in the elderly in Africa. Previous estimates for dementia in Southern Africa were set at around 2.1\% (compared to $5-10 \%$ worldwide). Preliminary estimates of the 10/66 DRG study (a worldwide population based survey in low and middle income countries) put the prevalence of dementia at around $6 \%$ for adults aged 65 years and older in urban black communities. ${ }^{3}$ Similarly in a survey conducted in Bangui and Brazzaville, the rates of dementia in urban areas were found to be $8.1 \%$ and $6.7 \%$. This correlates well with rates found in the developed world. ${ }^{4}$ In a comparison of depression in elderly African Americans and the Yoruba in Ibadan, Nigeria, the prevalence rate of depression was found to be similar at both the American and African sites. ${ }^{5}$ Notably, $66 \%$ of people with dementia worldwide live in undeveloped and developing countries, a figure expected to rise to $70 \%$ by $2040 .{ }^{3}$

The above statistics suggest that it might be incorrect to assume that Africa has lower numbers of disorders in the elderly, or that these disorders will not have an impact on the African economy, social well-being or health services. Additionally, Southern Africa experiences a unique burden in the form of the so called "orphaned elderly" due to the HIV pandemic. HIV afflicts mainly the young and middle tier of the population, resulting in the care of the family and incumbent costs falling largely on the elderly. Approximately $40 \%$ of households in South Africa are headed by an older person and it is they who are looking after an estimated 2 million orphans. ${ }^{6}$

\section{Challenges}

Issues pertaining to the care of the elderly are faced by a growing number of countries in the world. The major challenge is to improve and establish a multidisciplinary mental health care force with the appropriate knowledge, clinical skills and positive attitude to care for the elderly, train

\section{Correspondence}

Dr van Heerden

email: mvheerde@pgwc.gov.za other health professionals and liaise with government structures involved in health care and social services.

Core issues are the difficulties involved in the recruitment and retention of qualified staff working with the elderly. Attitudes and biases towards older adults and views on one's own aging influences choice of career, clinical practice, resource allocation and training outcomes.

As high as $40 \%$ of older adults in general practice and half in general hospitals may have mental health difficulties. ${ }^{\text {? }}$ All levels of health care professionals are faced with caring and managing the elderly. The establishment and maintenance of old age psychiatry or psychogeriatric units and recognition of old age psychiatrists (psychogeriatricians) will be an important strategy in improving the training of general psychiatrists, with a downstream transfer of skills to the complement of health care providers.

Linked to training is the establishment of research agendas by Universities and others involved with psychogeriatric service delivery. The interface with other disciplines in the neurosciences, such as neurology, geriatricians, and the neurosciences itself will be imperative in promoting research which is both appropriate and applicable to the African context as well as on par with international research standards.

Further challenges concern a wider group mandated with the care of the elderly. Old age psychiatry, being a relatively new discipline, has many legal aspects to it which still need to be addressed by the law and legislated in most African countries. In addition, non-profit organizations (NPO's) involved with care of the elderly, need to be empowered and supported. Home based care organizations (HBO's) do not have any representative body, or any regulations regarding minimum skills and standards in South Africa.

\section{Achievements}

Formerly, South Africa had old age psychiatry units at five Universities, whereas now there is only one facility shared by two. The private sectors' needs are in part being addressed by numerous clinics run by psychiatrists, neurologists and physicians. Teaching of old age psychiatry in South Africa is done at medical schools across the country and then mostly integrated into general psychiatric teaching barring for a few specialized neuropsychiatry and geriatric units. Regarding research, a large and robust epidemiological study of dementia, the Ibadan-Indiana project has been ongoing for the past two decades in Nigeria, the results being published in several international journal.s. ${ }^{8,9,10}$ Some limited research has been published from the early 1980's from South Africa. ${ }^{3,11,12}$

Collaboration between the Alzheimer 's disease Association and Nnamdi Azikiwe University Teaching Hospital has led to the establishment of a geriatric care centre at Dunukofia. In Ibadan, a Unit of Old Age Psychiatry, 
where special services are provided for older adults has been established. The Geriatric psychiatry programme of Ibadan is being replicated in northern Nigeria. Within the Association of Psychiatrists in Nigeria (APN), the old age Psychiatry interest group was formed. The group has held several meetings and made efforts in solidifying geriatric psychiatry in Nigeria. Recently the Faculty of Psychiatry of the West African College of Physicians approved the creation of Geriatric Psychiatry and the first draft of the curriculum has been finalized.

Old age psychiatry has been granted sub-specialty status by the Health and Professions Council of South Africa (HPCSA) and a Masters in Philosophy Programme has been initiated at the University of Stellenbosch in collaboration with the Colleges of Medicine of South Africa. The old age psychiatry subgroup of the South African society of psychiatrists (SASOP) was established in the late eighties and formalized constitutionally in 2007

The new Older Persons Act (13) 2006 which states that services must be rendered to older persons in South Africa is awaiting implementation. Care for the elderly largely falls under private institutions and NPO's which consist mainly of Non Governmental Organizations (NGO's), Community Based Organizations (CBO's) and Faith Based Organizations (FBO's).

The developments are encouraging and could increase an awareness and commitment to the care and treatment of the elderly in Africa.

\section{Surita van Heerden', Richard Uwakwe'2,} Felix Potochnick 'Stikland Hospital, Stellenbosch University, Cape Town, South Africa

${ }^{2}$ Faculty of Medicine,College of Health Sciences,Nnamdi Azikiwe University, Nnewi Campus, Nigeria

\section{References}

1. STATSSA (2008) Statistics South Africa - Statistical release P0302, mid-year population estimates.

2. WHO-AIMS Report on Mental Health System in Nigeria. WHO and Ministry of Health Ibadan, Nigeria 2006.

3. Press release, University of the Free State, 21 September 2010. http://www.ufs. ac.za/news/index.php?.sid=1871 \&cid=1 \&year=2010

4. Gaurchet M, M'belesso P, Nouanga AM, Bandzouzi B, Tabo A, Houinato et al Prevalence of dementia in elderly living in two cities of Central Africa: the EDAC survey. Dementia, Geriatric Cognitive Disorders.2010; 30(3):261-8.Epub 2010 Sep 16.

5. Baiyewu O, Smith-Gamble V, Lane K, Gureje O, Sujuan G, Ogunniyi A et al. Prevalence estimates of depression in elderly community dwelling African Americans in Indianapolis and Yoruba in Ibadan, Nigeria. International psychogeriatrics 2007; 19(4):679-689.

6. Draper B, Melding P, Brodaty H. Psychogeriatric Service Delivery: An International Perspective. Oxford University Press, 2005:184 - 189.

7. Ames D, Chui E, Lindesay J, Shulman KI. Guide to the Psychiatry of Old Age. Cambridge University Press. 2010: 134.

8. Ogunniyi A, Baiyewu O, Gureje O, Hall KS, Unverzagt F, Siu SH et al. Epidemiology of dementia in Nigeria: results from the IndianapolisIbadan study. European Journal of Neurology 2000; 7(5): 485-490.

9. Gureje O, Kola L, Afolabi E. The epidemiology of major depression in the Ibadan Study of Ageing. The Lancet 2007; 370: 957-964.

10. Gureje O, Kola L, Ademola A, Olley BO. Profile, co-morbidity and impact of insomnia in the Ibadan Study of Ageing. International Journal of Geriatric Psychiatry 2009;24 (7): 686

11. Gillis LS, Elk R, Le Fevre K, Joffe H. Reasons for referral of the elderly for psychiatric hospitalizations. SA Mediese tydeskrif, 31 Januarie 1981. P $150-152$.

12. Gillis LS, Elk R. Physical and mental incapacity in elderly white persons in Cape Town. SA Medical Journal 31 January 1981. P 147. 149 .

\section{INSTRUCTIONS FOR AUTHORS African Journal of Psychiatry (AJP)}

\section{WWW-ajop.c0.Za}

All manuscripts and correspondence should be emailed to:

Professor CP Szabo,

email: christopher.szabo@wits.ac.za 